\title{
Identifikasi Tingkat Kepuasan Pelanggan dengan Menggunakan Metode Servqual (Studi Kasus : PT. Perawang Kencana Motor
}

\author{
St Nova Meirizha, Rahmawati \\ Program Studi Teknik Industri, Fakultas Teknik \\ Universitas Muhammadiyah Riau \\ Jl. Tuanku Tambusai Ujung, Pekanbaru \\ E-mail:nomei_rizha@yahoo.co.id
}

\begin{abstract}
Abstrak
Sebuah perusahan jasa sangat erat kaitannya dengan pelanggan, karena salah satu dari karakteristik perusahaan jasa adalah berhubungan dengan konsumen secara intensif. Untuk itu tingkat kesuksesan perusahaan jasa dapat diukur dari seberapa besar tingkat kepuasan pelanggan terhadap pelayanan yang diberikan. Pada penelitian ini dilakukan identifikasi tingkat kepuasan pelanggan dengan metode Servqual pada PT.Perawang Kencana Motor yang merupakan salah satu industri yang bergerak dalam bidang penjualan motor dan penyediaan jasa service. Proses identifikasi dimulai dengan penyebaran kuesioner terbuka untuk mengetahui variabel apa saja yang harus diperhatikan dalam peningkatan kepuasan konsumen dan variabel tersebut akan digunakan pada kuesioner tertutup untuk melihat tingkat kepentingan dan tingkat kepuasan yang dirasakan konsumen terhadap kualitas kepuasan pada PT. Perawang Kencana Motor. Kemudian dilakukan uji validitas dan reliabilitas terhadap hasil penyebaran kuesioner. Setelah itu dilakukan perhitungan gap antara tingkat kepentingan dan tingkat kepuasan konsumen. Untuk mengetahui seberapa besar tingkat kepuasan konsumen maka dilakukan Importance Performance Analisys (IPA). Berdasarkan IPA maka diperoleh beberapa dimensi kualitas yang kurang baik dalam memberikan kepuasan terhadap pelayanan, yaitu mengenai kecepatan dan tanggapan karyawan dalam proses pembayaran, kecepatan karyawan dalam menanggapi keluhan dari pelanggan, keterampilan mekanik untuk menanggapi kerusakan yang terjadi pada sepeda motor, keramahan dan kesopanan dalam melayani pelanggan.
\end{abstract}

Kata kunci : Importance-Performance Analisys, Kepuasan, Kuesioner

\section{Pendahuluan}

\subsection{Latar Belakang}

Aspek pelayanan sangatlah penting bagi perkembangan bisnis perusahaan. Setiap perusahaan harus berusaha memberikan pelayanan yang optimal, karena terciptanya kepuasan pelanggan dapat memberikan manfaat. Manfaat yang di peroleh antara lain terciptanya hubungan yang baik antara perusahaan dengan pelanggan dan loyalitas.

PT.Perawang Kencana Motor yang merupakan salah satu industri yang bergerak dalam bidang penjualan motor dan penyediaan jasa service. Dalam melakukan pelayanan jasa kepada pelanggan PT.Perawang Kencana Motor selalu berusaha untuk optimal walaupun masih ada beberapa keluhan dari pelanggan. Berdasarkan latar belakang tersebutpuasan pelanggan atau pun keluhan pelanggan merupakan hal yang harus diperhatikan oleh setiap perusahaan maka dilakukan penelitian untuk mengidentifikasi tingkat kepuasan pelanggan pada PT. Perawang Kencana Motor.

\subsection{Tinjauan Pustaka}

Kualitas pelayanan adalah sebuah kinerja yang dapat ditawarkan oleh seseorang kepada orang lain. Kinerja ini dapat berupa tindakan yang tidak berwujud serta tidak berakibat pada kepemilikan barang apapun dan terhadap siapapun. Poin utamanya adalah pelayanan merupakan suatu tindakan yang dilakukan oleh seorang penjual kepada pembeli / konsumennya demi memenuhi kebutuhan dan keinginan konsumen. Perilaku tersebut bertujuan pada tercapainya kepuasan pelanggan itu sendiri. Sebuah pelayanan dapat dilakukan pada saat konsumen memilih produk maupun setelah selesai melakukan transaksi pembelian produk. 
Kepuasan pelanggan sendiri tidak mudah didefinisikan. Ada berbagai macam pengertian yang diberikan oleh pakar,antara lain : Menurut J.Supranto (2001:233), kepuasan konsumen adalah tingkat perasaan seseorang setelah membandingkan kinerja/hasil yang dirasakannya dengan harapannya. Menurut Day (dalam Tjitono 2003:102) menyatakan bahwa kepuasan adalah respon pelanggan terhadap evaluasi ketidaksesuaian yang dirasakan antara harapan sebelumnya (atau norma kinerja lainnya) dan kinerja aktual produk yang dirasakan setelah pemakaiannya.

Pengukuran tingkat kepusaan konsumen atau pelanggan erat hubungannya dengan mutu produk barang dan jasa. Pengukuran aspek mutu bermanfaat bagi pengelola jasa, yaitu (Supranto,1997).

a. Mengetahui dengan baik bagaimana jalannya atau bekerjanya proses pelayanan jasa.

b. Mengetahui dimana harus melakukan perubahan dalam upaya melakukan perbaikan secara terus menerus untuk memuaskan konsumen terutama untuk hal-hal yang dianggap penting oleh konsumen.

c. Menentukan apakah perubahan yang dilakukan mengarah ke perbaikan atau tidak (improvement).

d. Kepuasan konsumen harus diperhatikan penyedia jasa, konsumen yang tidak puas akan meninggalkan penyedia jasa dan akan beralih ke penyedia yang lain yang dapat memberikan pelayanan yang lebih baik sehingga konsumen akan merasa lebih puas. Makin banyak konsumen yang beralih menggunakan jasa ditempat lain maka menjadi indikasi terjadinya penurunan penyediaan jas (Supranto,1997).

Metode Servqual merupakan metode yang digunakan untuk mengukur kualitas layanan dari atribut masing-masing dimensi, sehingga akan diperoleh nilai gap (kesenjangan) yang merupakam selisih antara persepsi konsumen terhadap layanan yang telah diterima dengan harapan terhadap yang akan diterima. Pengukurannya metode ini dengan mengukur kualitas layanan dari atribut masingmasing dimensi, sehingga akan diperoleh nilai gap yang merupakan selisih antara persepsi konsumen terhadap layanan yang diterima dengan harapan konsumen terhadap layanan yang akan diterima. Namun, secara umum memang belum ada keseragaman batasan tentang konsep servive quality (servqual).

Berikut ini penjelasan mengenai ke-5 dimensi di atas, yaitu:
1. Tangibles (bukti terukur), menggambarkan fasilitas fisik, perlengkapan, dan tampilan dari personalia serta kehadiran para pengguna.

2. Reliability (keandalan), merujuk kepada kemampuan untuk memberikan pelayanan yang dijanjikan secara akurat dan handal.

3. Responsiveness (daya tanggap), yaitu kesediaan untuk membantu pelanggan serta memberikan perhatian yang tepat.

4. Assurance (jaminan), merupakan karyawan yang sopan dan berpengetahuan luas yang memberikan rasa percaya serta keyakinan.

5. Empathy (empati), mencakup kepedulian serta perhatian individual kepada para pengguna.

Diagram Importance Performance Analysis (IPA) ini (Gambar 3.4) terdiri dari empat kuadran, yaitu:

1. Kuadran I, wilayah yang memuat item-item dengan tingkat kepentingan yang relative tinggi tetapi kenyataannya belum sesuai dengan harapan pelanggan. Item-item yang masuk kuadran ini harus segera ditingkatkan kinerjanya.

2. Kuadran II, wilayah yang memuat item-item yang memiliki tingkat kepentingan relative tinggi dengan tingkat kepuasan yang relatif tinggi pula. Item yang masuk kuadran ini dianggap sebagai faktor penunjang bagi kepuasan pengguna sehingga harus tetap dipertahankan karena semua item ini menjadikan produk atau jasa tersebut unggul di mata pelanggan.

3. Kuadran III, wilayah yang memuat item - item dengan tingkat kepentingan yang relative rendah dan kenyataan kinerjanya tidak terlalu istimewa dengan tingkat kepuasan yang relatif rendah. Item yang masuk kuadran ini memberikan pengaruh sangat kecil terhadap manfaat yang dirasakan oleh pengguna.

4. Kuadran IV, wilayah yang memuat item-item dengan tingkat kepentingan yang relative rendah dan dirasakan oleh pengguna terlalu berlebihan dengan tingkat kepuasan yang relatif tinggi. Biaya yang digunakan untuk menunjang item yang masuk kuadran ini dapat dikurangi agar dapat menghemat biaya pengeluaran.

\section{Methodologi}

Adapun tahapan penelitian yang dilakukan adalah:

A. Penelitian Pendahuluan

Penelitian pendahuluan ini adalah dengan melakukan survey awal terhadap keluhan konsumen dari PT. Perawang Kencana Motor.

B. Perumusan masalah 
Bagaimana mengidentifikasi tingkat kepuasan pelanggan PT. Perawang Kencana Motor.

C. Tujuan Penelitian

Tujuan penelitian adalah untuk mengetahui tingkat kepuasan pelanggan terhadap kualitas pelayanan yang diberikan PT. Perawang Kencana Motor.

D. Pengumpulan Data

Data yang dikumpulkan terdiri dari data primer yaitu berupa data kuesioner, dan untuk data sekunder.

E. Pengolahan Data

Adapun tahapan pengolahan data pada penelitian ini adalah identifikasi variabel yang mempengaruhi kepuasan konsumen dengan menggunakan kuesioner terbuka, merancang kuesioner tertutup dengan menggunakan dimensi servqual, uji validitas dan reliabilitas terhadap hasil penyebaran kuesioner, perhitungan gap antara kepentingan dan kepuasan konsumen, dan penentuan tingkat kepuasan pelanggan dengan Importance Performance Analysis (IPA).

\section{Hasil dan Pembahasan}

\subsection{Identifikasi Variabel yang Mempengaruhi Kepuasan Konsumen}

Setelah melakukan pengamatan pada permasalahan-permasalahan yang terjadi di instansi tersebut maka digunakan kuosioner terbuka untuk mengetahui variabel apa saja yang mempengaruhi kepuasan konsumen di PT. Perawang Kencana Motor.

Penyebaran kuesioner terbuka ini bertujuan untuk mempermudah dalam mengetahui variabel apa saja yang harus diperhatikan dalam peningkatan kepuasan konsumen dan variabel tersebut akan digunakan pada kuesioner tertutup untuk melihat tingkat kepentingan dan tingkat kepuasan yang dirasakan konsumen terhadap kualitas kepuasan pada PT. Perawang Kencana Motor. Dari penyebaran kuesioner terbuka tersebut dapat di lihat keluhan yang dianggap penting yang mempengaruhi kepuasan konsumen berdasarkan jawaban sebagai berikut :

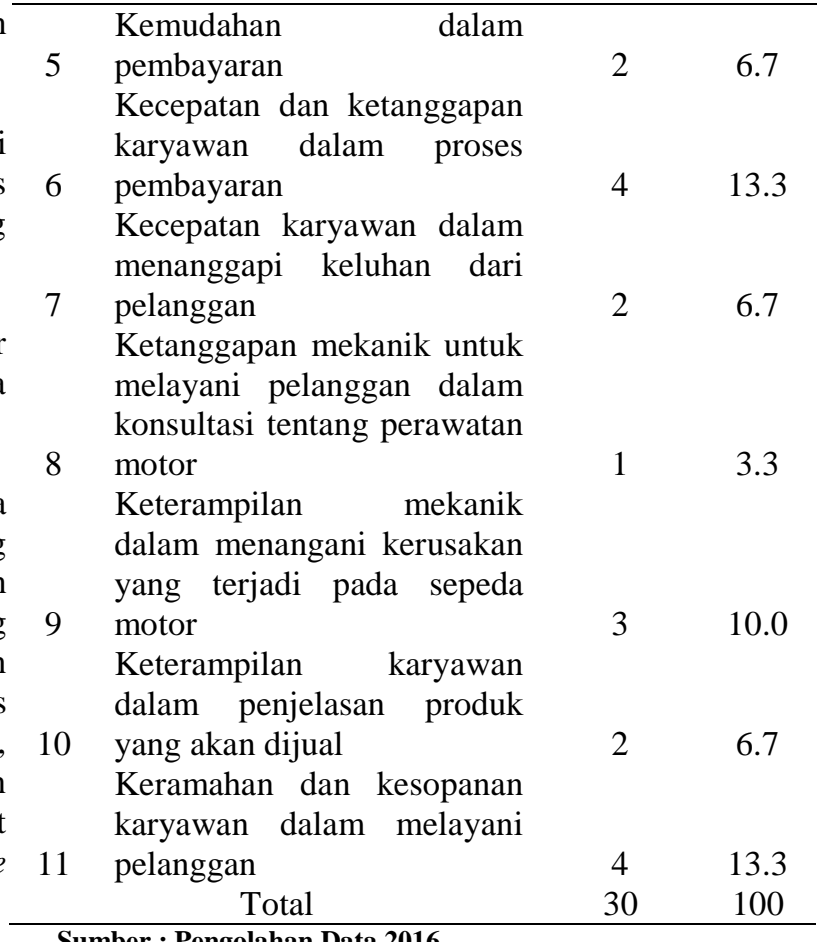

Sumber : Pengolahan Data 2016

\subsection{Perancangan kuesioner tertutup dengan Menggunakan Dimensi Servqual}

Setelah mendapatkan dan menentukan variabelvariabel atau karakteristik berdasarkan kuesioner terbuka maka dapat dilanjutkan kepada kuesioner tertutup, dalam pengukuran kepuasan konsumen yang ada pada kantin saat ini dilakukan atau dilaksanakan perbaikan dan hasil yang terjadi setelah pelaksanaan kegiatan dalam pengukuran kepuasan dalam tingkat yang paling penting diperhatikan adalah pada saat pengumpulan dua informasi yaitu karakteristik pada kepuasan yang dianggap atau dirasakan penting oleh konsumen dan tingkat kepuasan yang dirasakan oleh konsumen.

Pada dasarnya untuk mengumpulkan dua informasi kunci tersebut digunakan kuesioner tertutup yang menjadikan variabel-variabel yang dihasilkan dari penyebaran kuesioner terbuka.

Skala servqual meliputi lima dimensi kualitas jasa. Dimensi Kualitas Pelanggan dijelaskan pada tabel dibawah ini yaitu sebagai berikut :

Tabel 1.

Data Keluhan Konsumen

\begin{tabular}{|c|c|c|c|c|c|}
\hline \multirow{3}{*}{ No } & \multicolumn{3}{|c|}{ Data Keluhan Konsumen } & \multirow{2}{*}{\multicolumn{2}{|c|}{$\begin{array}{c}\text { Tabel } 2 . \\
\text { Dimensi Kualitas Pelanggan }\end{array}$}} \\
\hline & \multirow{2}{*}{ Variabel } & \multirow{2}{*}{$\begin{array}{l}\text { Jumlah } \\
\text { Keluhan }\end{array}$} & \multirow{2}{*}{$\%$} & & \\
\hline & & & & & nensi Kualitas Pelanggan \\
\hline 1 & $\begin{array}{l}\text { Ruang Tunggu di bagian } \\
\text { bengkel tidak nyaman }\end{array}$ & 5 & 16.7 & Reliability & $\begin{array}{l}\text { 1. Kesesuaian harga dengan hasil yang } \\
\text { diterima }\end{array}$ \\
\hline 2 & Area Parkir sempit & 2 & 6.7 & (eandalan) & 2. Kemudahan dalam pembayaran \\
\hline 3 & $\begin{array}{l}\text { Pakaian karyawan tidak } \\
\text { seragam } \\
\text { Kesesuaian harga dengan }\end{array}$ & 3 & 10.0 & $\begin{array}{l}\text { Assurance } \\
\text { (Asuransi) }\end{array}$ & $\begin{array}{l}\text { 3. Mengenai keterampilan mekanik } \\
\text { dalam menangani kerusakan yang } \\
\text { terjadi pada mesin motor }\end{array}$ \\
\hline 4 & hasil yang diterima & 2 & 6.7 & & \\
\hline
\end{tabular}

SURYA TEKNIKA Vol. 1 No. 4, Juni 2016 : 75 - 81 
4. Menganai ketrampilan karyawan dalam penjelasan produk yang akan dijual

5. Mengenai fasilitas ruang tunggu di bagian bengkel

Tangibel

(Bukti Fisik)

6. Mengenai Area parkir yang sempit

7. Mengenai Pakaian Karyawan tidak seragam

8. Mengenai keramahan dan kesopanan karyawan dalam melayani pelanggan

9. Mengenai kecepatan dan ketanggapan karyawan dalam proses pembayaran

Responsivene s (Daya Tanggap)

10.Mengenai kecepatan karyawan dalam menanggapi keluhan dari pelanggan

11.Mengenai ketanggapan mekanik untuk melayani pelanggan dalam konsultasi tentang perawatan motor.

\section{Sumber : Pengolahan Data 2016}

Teknik sampling yang digunakan untuk meneliti kualitas pelayanan ini adalah Teknik Simple Random Sampling. Hal ini dilakukan karena dalam memilih sampel dengan memberikan kesempatan yang sama kepada semua anggota populasi untuk ditetapkan sebagai anggota sampel.

Karakteristik Responden

1. Karakteristik Responden Berdasarkan Jenis Kelamin

Berdasarkan hasil penelitian yang diperoleh dari kuesioner, maka diperoleh data tentang jenis kelamin responden dapat dilihat pada tabel berikut

Tabel 3.

Distribusi Jenis Kelamin Responden Penelitian

\begin{tabular}{|c|c|c|c|}
\hline No & $\begin{array}{c}\text { Jenis } \\
\text { Kelamin }\end{array}$ & $\begin{array}{c}\text { Jumlah } \\
\text { Orang }\end{array}$ & Presentase \\
\hline 1 & Laki-laki & 45 Orang & $82 \%$ \\
\hline \multirow[t]{2}{*}{2} & Perempuan & 10 Orang & $18 \%$ \\
\hline & Total & 55 Orang & $100 \%$ \\
\hline
\end{tabular}

Sumber : Pengolahan Data 2016

Berdasarkan data pada tabel di atas, menunjukkan bahwa sebagian besar responden dalam penelitian ini adalah berjenis kelamin lakilaki sebanyak 45 orang responden, sedangkan yang paling sedikit adalah responden berjenis kelamin perempuan yakni sebanyak 10 orang responden.

2. Karakteristik Responden Berdasakan Pekerjaan

Berdasarkan hasil penelitian yang diperoleh dari penyebaran kuesioner, maka diperoleh data jumlah responden berdasarkan pekerjaan dapat dilihat pada tabel berikut :
Tabel 4.

Distribusi Responden Berdasarkan Pekerjaan

\begin{tabular}{clcc}
\hline No & \multicolumn{1}{c}{ Pekerjaan } & $\begin{array}{c}\text { Jumlah } \\
\text { Orang }\end{array}$ & Presentase \\
\hline 1 & Karyawan & 35 Orang & $64 \%$ \\
2 & Wirasuwasta & 13 Orang & $24 \%$ \\
3 & Mahasiswa & 3 Orang & $5 \%$ \\
4 & Ibu Rumah Tangga & 4 Orang & $7 \%$ \\
\multicolumn{2}{c}{ Total } & 55 Orang & $100 \%$ \\
\hline Sumber : Pengolahan Data, 2016
\end{tabular}

Berdasarkan data pada tabel 4 diatas, menunjukkan bahwa sebagian besar responden dalam penelitian ini bekerja sebagai karyawan pada sebuah pabrik sebanyak 35 orang. Sedangkan responden yang paling sedikit bekerja sebagai Mahasiswa sebanyak 3 orang.

\subsection{Uji Validitas dan Reliabilitas}

\subsubsection{Uji Validitas}

Uji Kevaliditasan sebuah alat ukur ditunjukkan dari kemampuan alat ukur tersebut mampu mengukur apa yang seharusnya diukur (Roni Andespa,2011:89), Uji validitas berarti menguji apakah suatu instrumen memiliki ketepatan atau kecermatan dalam mengukur apa yang ingin diukur.

Uji instrument dikatakan valid apabila nilai $r$ hitung > r tabel atau koefisien validitas, artinya alat ukur yang digunakan valid. Dengan menggunkan software SPSS.16 diketahui nilai uji validitas seperti dilihat pada tabel berikut :

Tabel 5.

Rekapitulasi Nilai Korelasi Tingkat Kepentingan Dan Kepuasan

\begin{tabular}{|c|c|c|c|c|c|}
\hline \multirow{2}{*}{ Variabel } & \multirow{2}{*}{ Item } & \multicolumn{2}{|c|}{ Nilai r (korealasi) } & Koevisien & \multirow{2}{*}{ Keterangan } \\
\cline { 3 - 6 } & & Kepentingan & Kepuasan & Validitas & \\
\hline \multirow{2}{*}{ Reliability } & 1 & 0,506 & 0,828 & 0,266 & Valid \\
\cline { 2 - 6 } & 2 & 0,622 & 0,788 & 0,266 & Valid \\
\hline \multirow{2}{*}{ Assurance } & 3 & 0,489 & 0,806 & 0,266 & Valid \\
\cline { 2 - 6 } & 4 & 0,651 & 0,713 & 0,266 & Valid \\
\hline \multirow{3}{*}{ Tangibel } & 5 & 0,439 & 0,731 & 0,266 & Valid \\
\cline { 2 - 6 } & 6 & 0,549 & 0,756 & 0,266 & Valid \\
\cline { 2 - 6 } & 7 & 0,330 & 0,732 & 0,266 & Valid \\
\hline Emphaty & 8 & 0,448 & 0,654 & 0,266 & Valid \\
\hline \multirow{3}{*}{ Responsivenes } & 9 & 0,300 & 0,292 & 0,266 & Valid \\
\cline { 2 - 6 } & 10 & 0,562 & 0,673 & 0,266 & Valid \\
\cline { 2 - 6 } & 11 & 0,626 & 0,778 & 0,266 & Valid \\
\hline
\end{tabular}

Sumber : Pengolahan Data 2016

Dari tabel diatas terlihat bahwa pada nilai $\mathrm{r}$ (korelasi) kepentingan dan nilai $r$ (korelasi) kepuasan yang didapatkan melalui perhitungan rumus manual diatas harus dibandingkan dengan nilai $r$ tabel yang $r$ tabel terdapat pada lampiran yang memiliki derajat kebebasan dengan perhitungan sebagai berikut : $(\mathrm{dF})=\mathrm{N}-2=55-2=$ 53, Maka dari perhitungan diatas diperoleh nilai $\mathrm{r}$ tabel pada taraf signifikan 5\% adalah 0,266.

Dalam mengambil sebuah keputusan yang menyatakan valid atau tidak validnya sebuah 
karakteristik kualitas didasarkan kepada nilai korelasi antara kepentingan dan kepuasan lebih besar dari pada nilai $r$ tabel maka karakteristik kualitas dinyatakan valid dan maupun sebaliknya, berdasarkan dari hasil uji validitas maka semua pertanyaan karakteristik dinyatankan valid karena nilai kepentingan dan kepuasan lebih besar dari pada $\mathrm{r}$ tabel.

\subsubsection{Uji Validitas}

Reliabilitas adalah alat untuk mengukur suatu kuesioner yang merupakan indikator dari variabel. Suatu kuesioner dikatakan reliable atau handal jika jawaban seseorang terhadap pernyataan adalah konsisten atau stabil dari waktu ke waktu.

SPSS memberikan fasilitas untuk mengukur reliabilitas dengan uji statistic Cronbach Alpha $(\alpha)$. Suatu variabel dikatakan reliable jika memberikan nilai Cronbach Alpha > 0.60 (Nunnally, 1967).

Tabel 6.

Uji Reliabilitas Tingkat Kepentingan Reliability Statistics

\begin{tabular}{l|l}
\hline Cronbach's Alpha & N of Items \\
\hline .710 & 11 \\
\hline
\end{tabular}

Tabel 7.

Uji Reliabilitas Tingkat Kepuasan

\begin{tabular}{l|l}
\hline \multicolumn{2}{l}{ Reliability Statistics } \\
\hline Cronbach's Alpha & N of Items \\
\hline .892 & 11 \\
\hline
\end{tabular}

Pada uji reliabilitas penilaian berdasarkan tingkat kepentingan dan tingkat kepuasan yang terdapat diatas diketahui bahwa suatu penelitian nilai Cronbach's Alphanya lebih dari nilai $\mathrm{r}$ tabel pada $\mathrm{N}=55$ dan taraf signifikan $5 \%$ yaitu 0,266 dengan demikian dapat disimpulkan bahwa variabel ini adalah reliable. Dan hasil pengujian reliabilitas menunjukkan bahwa nilai koefisien reliabilitas lebih besar dari ketentuan yaitu 0,60 sehingga instrument yang digunakan dinyatakan reliable

\subsection{Perhitungan Gap Kepentingan (Harapan) dan Kepuasan}

Perhitungan gap (kesenjangan) antara tingkat kepentingan dan kepuasan dapat dilihat pada tabel 8 .

Berdasarkan tabel 8 dapat dilihat bahwa semua indikator bernilai negatif. Hal ini memperlihatkan bahwa pelayanan yang diberikan oleh PT. Perawang Kencana Motor masih belum sesuai dengan harapan pelanggan.
Tabel 8.

Gap Indikator

\begin{tabular}{|l|c|c|c|}
\hline \multicolumn{1}{|c|}{ Indikator } & Kepuasan & Kepentingan & Gap \\
\hline $\begin{array}{l}\text { Ruang Tunggu di bagian bengkel tidak } \\
\text { nyaman }\end{array}$ & 3.15 & 4.48 & -1.33 \\
\hline Area Parkir yang sempit & 3.09 & 4.85 & -1.76 \\
\hline Pakaian karyawan yang tidak seragam & 3.33 & 4.80 & -1.47 \\
\hline Kesesuaian harga dengan hasil yang diterima & 3.13 & 4.67 & -1.54 \\
\hline Kemudahan dalam pembayaran & 3.22 & 4.67 & -1.45 \\
\hline $\begin{array}{l}\text { Kecepatan dan ketanggapan karyawan dalam } \\
\text { proses pembayaran }\end{array}$ & 2.76 & 4.84 & -2.08 \\
\hline $\begin{array}{l}\text { Kecepatan karyawan dalam menanggapi } \\
\text { keluhan dari pelanggan }\end{array}$ & 2.65 & 4.76 & -2.11 \\
\hline $\begin{array}{l}\text { Ketanggapan mekanik untuk melayani } \\
\text { pelanggan dalam konsultasi tentang perawatan } \\
\text { motor }\end{array}$ & 3.24 & 4.69 & -1.45 \\
\hline $\begin{array}{l}\text { Keterampilan mekanik dalam menangani } \\
\text { kerusakan yang terjadi pada sepeda motor }\end{array}$ & 2.44 & 4.84 & -2.40 \\
\hline $\begin{array}{l}\text { Keterampilan karyawan dalam penjelasan } \\
\text { produk yang akan dijual }\end{array}$ & 3.07 & 4.64 & -1.57 \\
\hline $\begin{array}{l}\text { Keramahan dan kesopanan karyawan dalam } \\
\text { melayani pelanggan }\end{array}$ & 2.96 & 4.75 & -1.79 \\
\hline Sum . . .
\end{tabular}

Sumber : Pengölahân Data, 2016

\subsection{Importance Performance Analysis}

Hasil IPA (Importance-Performance Analisys) ini disajikan dalam bentuk diagram IPA :

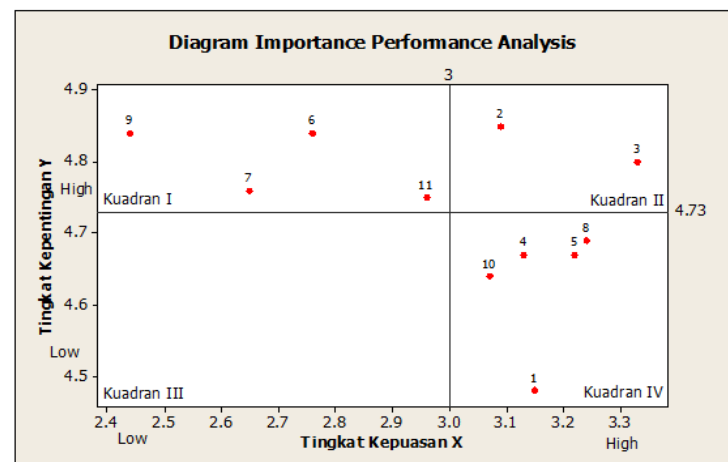

Gambar 1. Diagram Cartecius Hasil Pengolahan Metode IPA Sumber : Pengolahan Data, 2016

Berdasarkan hasil analisa yang dilakukan dapat diketahui posisi kualitas pelayanan yang diberikan oleh PT. Perawang Kencana Motor seperti yang dijelaskan dibawah ini :

1. Kuadran I, wilayah yang memuat item-item dengan tingkat kepentingan yang relative tinggi tetapi kenyataannya belum sesuai dengan harapan pelanggan. Sehingga Item-item yang masuk kuadran ini perlu perhatian utama dari pihak perusahaan. Langkah-langkah yang dapat ditempuh adalah dengan melakukan perbaikan secara terus menerus sehingga item-item yang ada pada kuadran ini meningkat.

Item-item nya yaitu :

- Kecepatan dan ketanggapan karyawan dalam proses pembayaran

- Kecepatan karyawan dalam menanggapai keluhan dari pelanggan

- Keterampilan mekanik dalam menanggani kerusakan yang terjadi pada sepeda motor

- Keramahan dan kesopanan karyawan dalam melayani pelanggan

2. Kuadran II, wilayah yang memuat item-item yang memiliki tingkat kepentingan relative tinggi dengan tingkat kepuasan yang relatif 
tinggi pula. Item yang masuk kuadran ini dianggap sebagai faktor penunjang bagi kepuasan pengguna sehingga harus tetap dipertahankan karena semua item ini menjadikan produk atau jasa tersebut unggul di mata pelanggan.

Item-item nya yaitu :

- Area Parkir yang sempit

- Pakaian karyawan yang tidak seragam

3. Kuadran III, wilayah yang memuat item- item dengan tingkat kepentingan yang relative rendah dan kenyataan kinerjanya tidak terlalu istimewa dengan tingkat kepuasan yang relatif rendah. Item yang masuk kuadran ini memberikan pengaruh sangat kecil terhadap manfaat yang dirasakan oleh pengguna. Pada kuadran III ini tidak ada item-item yang tertera didalamnya.

4. Kuadran IV, wilayah yang memuat item-item dengan tingkat kepentingan yang relative rendah dan dirasakan oleh pengguna terlalu berlebihan dengan tingkat kepuasan yang relatif tinggi. Biaya yang digunakan untuk menunjang item yang masuk kuadran ini dapat dikurangi agar dapat menghemat biaya pengeluaran.

Item-itemnya yaitu :

- Ruang tunggu dibagian bengkel tidak nyaman

- Kesesuaian harga dengan hasil yang diterima

- Kemudahan dalam pembayaran

- Ketanggapan mekanik untuk melayani pelanggan dalam konsultasi tentang perawatan motor

- Keterampilan karyawan dalam menjelaskan produk yang akan dijual

\section{Simpulan}

Dari hasil pengolahan data maka dapat disimpulkan bahwa dengan menggunakan metode Importance Performance Analysis (IPA) dan diagram cartesius terdapat 4 kuadran yang menjadi tingkatan kepuasan pelanggan terhadap kualitas yang diberikan PT. Perawang Kencana Motor yaitu :

1. Terdapat 4 item yang masuk kedalam Kuadran I yang mana merupakan tingkat kepentingan yang relative tinggi tetapi kenyataannya belum sesuai dengan harapan pelanggan, item-item nya yaitu mengenai kecepatan dan tanggapan karyawan dalam proses pembayaran, kecepatan karyawan dalam menanggapi keluhan dari pelanggan, keterampilan mekanik untuk menanggapi kerusakan yang terjadi pada sepeda motor, keramahan dan kesopanan dalam melayani pelanggan. Hal ini menunjukkan bahwa item-item tersebut kurang baik dalam memberikan kepuasan terhadap pelayanan. Karena item-item tersebut dianggap penting namun pelaksanaannya masih dirasakan kurang oleh pelanggan.

2. Kuadran II, wilayah yang memuat item-item yang memiliki tingkat kepentingan relative tinggi dengan tingkat kepuasan yang relatif tinggi pula. Item-item nya yaitu area parkir dan kedisiplinan karyawan. Sehingga pada item ini perlu dipertahankan prestasinya bahkan lebih ditingkatkan lagi.

3. Kuadran III, wilayah yang memuat item - item dengan tingkat kepentingan yang relative rendah dan kenyataan kinerjanya tidak terlalu istimewa dengan tingkat kepuasan yang relatif rendah. Item-itemnya berdasarkan diagram kartecius tidak tertera didalamnya.

4. Kuadran IV, wilayah yang memuat item-item dengan tingkat kepentingan yang relative rendah dan dirasakan oleh pengguna terlalu berlebihan dengan tingkat kepuasan yang relatif tinggi. Item-itemnya terdiri dari Ruang tunggu dibagian bengkel, Kesesuaian harga dengan hasil yang diterima, Kemudahan dalam pembayaran, Ketanggapan mekanik untuk melayani pelanggan dalam konsultasi tentang perawatan motor, Keterampilan karyawan dalam menjelaskan produk yang akan dijual. Hal ini bahwa pelanggan menganggap itemitem kurang penting.

\section{Saran}

Setelah mengetahui tingkat kepuasan pelanggan pada PT. Perawang Kencana Motor disarankan untuk membuat usulan perbaikan terhadap kualitas pelayanan yang diberikan kepada konsumen pada penelitian selanjutnya.

\section{Daftar Pustaka}

[1] Dias-Marti el al. (2000), mengemukakan lima dimensi dalam menentukan kualitas jasa pada tempat wisata, yaituprofesionalism, tangibles, complementary offer, basic benefit, dan location. Jurnal Online Institut Teknologi Nasional

[2] Kotler, Philip dan A.B.Susanto. 2000, Manajemen Pemasaran : Analisis Perencanaan, Implementasi, dan Pengendalian. Yogyakarta : Salemba Empat

[3] Krisna Dewi, Luh Putu. 2010, Analisis Faktor-faktor Yang Mempengaruhi Kepuasan Pelanggan Produk L'Oreal Paris , Skripsi, Fakultas Ekonomi Universitas Diponegoro. 
ISSN: 2354-6751

[4] NILASARI, ESWIKA (2015). Pengaruh Kualitas Pelayanan Terhadap Kepuasan Konsumen pada Dealer PT. Ramayana Motor Sukoharjo. Universitas Islam Batik Surakarta.

[5] Panduan Kerja Praktek Teknik Industri Universitas Muhammadiyah Riau (2015)

[6] Parasuraman, A., Zeithalm, V., dan Berry L., 1988. "SERVQUAL: A Multiple item Scale Measuring Consumer Perceptions of Service Quality”. Journal of Retailing, Spring, pp.1240 